\title{
Honoring a Friendship: The Blake-Stoudemire African American Collection, Lincolnton's Jonas Branch Library
}

\author{
by Thomas Kevin B. Cherry
}

"Y ou might say it was a dark and stormy night back in February," Lesley Levine, Head of Lincolnton's Jonas Branch of the Gaston-Lincoln Regional Library laughed, "But we had a crowd. Everyone had a wonderful time. We didn't have much of a program, though. Basically people looked at the books and mingled."

And those at that reception that could, surely remembered. They remembered two little boys, Alan Stoudemire and Boyce Blake, one White and one Black, who grew up on neighboring farms in the 1950s. Playing in the creek and on improvised ballfields, they were the best of friends. And although the world they lived in didn't promote interracial friendships, theirs survived.

It survived inequities that even a child could see: a pool closed to Boyce but open to Alan. It survived the days of early school desegregation when as seniors Boyce and Alan's relationship helped ease tensions at Lincolnton High School. It survived years of separation, in which Boyce became the first member of his family to attend college, and Alan went to the University of North Carolina, then on to medical school and a residency at the University of Colorado Medical Center. It survived Alan's struggle with depression following bone cancer, and Boyce's battle with Lou Gehrig's Disease.

The story of their friendship made the Charlotte Observer and Reader's Digest and is told in Alan's book, Sometimes a Memory, which will be published in the spring by Atlanta's Cherokee Press. And now it is a story that is remembered and honored by the Blake-Stoudemire African American Collection at Lincolnton's Jonas Branch Library.

Following Boyce Blake's death from Lou Gehrig's disease, Alan Stoudemire decided to honor his friend's memory and their friendship by establishing a collection of books concerning African American culture and history at their hometown library. Lesley Levine remembers, "He just called me out of the blue. I'd never met him. He said, 'Would you think about this.' I said, 'Absolutely.' This is really an exciting prospect for us, and it grew from there."

Alan Stoudemire's mother, Louise Stoudemire, had been Lincolnton's librarian for 25 years. "She was at all three buildings," he remembers, "I grew up with the library, and I felt like it would be a nice community-oriented thing to do, building up a really first-class African American Collection." Alan who is hospitalized with a recurrence of cancer continued, "It was a good way to combine my family's commitment to the li- brary and the community, as well as honor Boyce's and my friendship."

Lesley Levine is excited about the way Blake-Stoudemire has enhanced her collection. "[Alan] is pretty willing to give us what we need. We've bought books and videos. We've bought Roots on video, for example; we could never have afforded that before. We have interesting material on Black music, church, a lot of social history and sets for children on African-American authors, inventors, that sort of thing. Before this gift, we would have had to have been selective, but with this gift we have been able to buy the whole set."

She explains, "If we would have bought a book anyway, I don't use Blake-Stoudemire. I use it only if I would have said before, 'If only we had the money.'"

It was that "if-only" money that Alan Stoudemire provided. "My first goal was to give them discretionary funds," Alan recalls, but he couldn't help but become more active, "The more I studied it, as the turn-of-the-century best-books lists came out, I went through and picked out the ones that were written by Black authors and about Blacks and picked out the ones that the library had. Actually they had a good collection before, but [the Blake-Stoudemire Collection] rounds it out."

But Alan Stoudemire wants to do more than create a wellrounded collection; he wants to maintain it. "I think that once we complete this part of it, I want the library to have these discretionary funds in perpetuity. It will be a discretionary, private endowment." After a pause he adds, "There might be other funds like this that have grown out of a Black-White friendship, but I'm not aware of one."

Boyce's sister, Donna Tolliver Blake, says that her family appreciates the library's Blake-Stoudemire collection, too. "Personally, it made me feel real good. That someone would do this for somebody who wasn't a president or anything like that. Just somebody who had been good in life. A regular good person. It would have made Boyce feel good. He wasn't the type to boast or anything like that, but he would have enjoyed the recognition of what he tried to do."

When Donna Tolliver Blake goes to the library now, she takes her sixteen- and twelve-year-old boys, both of whom helped Boyce in his final illness, "And we look at those books, and we check them out. The boys have enjoyed the collection."

Lesley Levine sums it up, "If I'm at the desk, I notice when one of those books goes out." There is a pause, "We would not have this otherwise." 

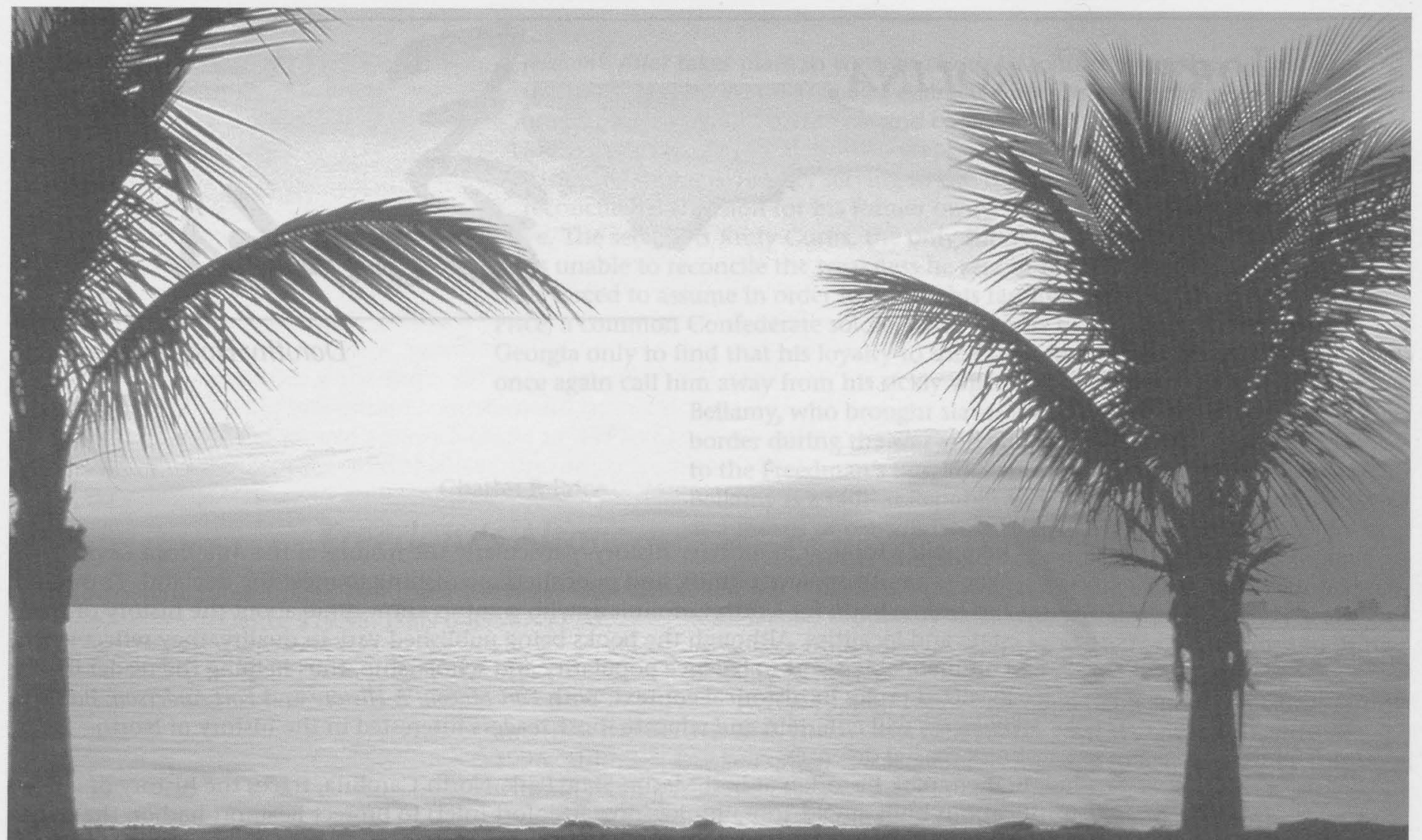

Simple meditation \& relaxation by Joel Levey and Michelle Levey

Conari Press, 1999

ISBN: 1573241512

Hardcover

$\$ 13.95$

Instant calm by Paul Wilson

Penguin USA, 1999

ISBN:0452274338

Paperback

$\$ 12.95$

Stress that motivates

Natl Book Network, 1999

ISBN:1560525371

Paperback

$\$ 12.95$

Boiling point: the high cost of unhealthy anger to individuals and society by Jane Middletown-Moz Health Communications, 1999

ISBN:1558746676

Paperback

$\$ 10.95$

Calm at work: breeze through your day feeling calm, relaxed, and in control by Paul Wilson Plume, 1999

ISBN:0452280427

Paperback

$\$ 12.95$

Every person is a collection of possibilities. They come to your library to answer questions, to find reasons, to turn possibilities into realities. Making sure they have a wide variety of resources is no small task. We'd like to help. Ours is the largest selection of media in the industry, allowing you to provide your patrons with whatever they need. Move quickly and easily through our offerings using our experienced staff and intuitive software to place your orders both on-line and off. All orders are shipped promptly so neither you nor your patrons will be kept waiting. It will be one less stress in everyone's day.

\title{
BAKER\&TAYLOR \\ Information and Entertainment Services
}

\author{
1. 800.775 .1800 \\ www.btol.com
}

